Banco, Volume 1, November 2019

\title{
PERAN KOPERASI PONDOK PESANTREN DDI LILBANAT PAREPARE DALAM MENINGKATKAN KESEJAHTERAAN GURU DAN SANTRI
}

\author{
Hikmawati \\ IAIN Parepare \\ hikmawati21@iainparepare.ac.id \\ Syahriyah Semaun \\ IAIN Parepare \\ syahriyah@iainparepare.ac.id \\ Damira \\ IAIN Parepare \\ damira@iainparepare.ac.id
}

\begin{abstract}
School cooperatives are cooperatives whose members are students or students of a school that serves as a forum for educating the growing awareness of cooperatives among students. For this reason, we need a forum that is expected to be able to achieve these objectives, namely school cooperatives. Cooperatives have a direct contribution to the welfare of their members because cooperatives have the principle of kindship and also the function of cooperatives for the welfare of their members. DDI Lilbanat Islamic boarding school as one of the business units, Islamic boarding schools aim to meet the needs of teachers and students in daily life. This research was conducted by raising the issue of: 1 . How the efforts of DDI Lilbanat boarding school cooperatives in meeting the needs and improving the welfare of teachers and students, 2 . How is the function of the DDI Lilbanat boarding school cooperatives in order to improve the welfare of teachers and students.

This type of research used in this thesis is a qualitative descriptive method, the data in this study were obtained from primary data and secondary data. Data collection techniques used were observation, interviews, and documentation. The data analysis technique used is the inductive method and the deductive method.

The results showed that: 1. The efforts of DDI Lilbanat Islamic Boarding School Cooperative in meeting the needs and improving the welfare of teachers and students by improving both the activities of cooperatives, the management of their business units and their cooperative management. The welfare of members can be improved by building and developing the potential and economic capabilities of members (teachers and students), helping members' needs, fostering awareness of cooperatives and fostering a sense of responsibility, discipline and cooperative spirit
\end{abstract}

Keywords: Coorporation, W alfare, Student and Teacher, Boarding School 


\begin{abstract}
Abstrak
Koperasi sekolah adalah koperasi yang anggotanya para siswa atau murid dari suatu sekolah yang berfungsi sebagai wadah untuk mendidik tumbuhnya kesadaran berkoperasi di kalangan siswa. Untuk itu, diperlukan suatu wadah yang diharapkan mampu mencapai tujuan tersebut yaitu koperasi sekolah. Koperasi memiliki konstribusi langsung terhadap kesejahteraan anggotanya karena koperasi berasas kekeluargaan dan bertujuan mensejahterakan anggotanya. Pondok pesantren DDI Lilbanat sebagai salah satu unit usaha. Koperasi pesantren betujuan untuk memenuhi kebutuhan guru dan santri dalam kehidupan sehari-hari. Penelitian ini dilakukan dengan mengangkat permasalahan tentang: 1. Bagaimana upaya koperasi pondok pesantren DDI Lilbanat dalam memenuhi kebutuhan dan meningkatkan kesejahteraan guru dan santri, 2. Bagaimana fungsi koperasi pondok pesantren DDI Lilbanat dalam rangka meningkat kesejahteraan guru dan santri.

Jenis penelitian yang digunakan dalam skripsi ini adalah metode deskriptif kualitatif. Data dalam penelitian ini diperoleh dari data primer dan data sekunder. Teknik pengumpulan data yang digunakan adalah observasi, wawancara, dan dokumentasi. Adapun teknik analisis datanya yang digunakan yaitu metode induktif dan metode deduktif.

Hasil penelitian menunjukkan bahwa: 1. Upaya Koperasi Pondok Pesantren DDI Lilbanat dalam memenuhi kebutuhan dan meningkatkan kesejahteraan guru dan santri, yaitu dengan memperbaiki baik itu kegiatan-kegiatan koperasi, pengelolaan unit-unit usahanya maupun manajemen koperasinya agar kebutuhan anggota (guru dan santri) terpenuhi dan 2. kesejahteraan anggota dapat ditingkatkan dengan membangun dan mengembangkan potensi dan kemampuan ekonomi anggota (guru dan santri), membantu kebutuhan anggota, menumbuhkan kesadaran berkoperasi dan membina rasa tanggung jawab, disiplin serta berjiwa koperasi.
\end{abstract}

\title{
Kata Kunci: Peran Koperasi, Kesejabteraan, Guru dan Santri, Pesantren
}

\section{A. Pendahuluan}

Pondok pesantren (ponpes) adalah salah satu lembaga pendidikan Islam tertua di Indonesia. Keberadaan dan perannya dalam mencerdaskan kehidupan bangsa telah diakui oleh masyarakat. Dalam perkembangannya, pondok pesantren berfungsi sebagai pusat bimbingan dan pengajaran ilmu-ilmu agama islam (tafaqquh fi aldin) yang telah banyak melahirkan ulama, toko masyarakat dan mubaligh. Seiring dengan laju pembangunan dan tuntutan zaman serta perkembangan ilmu pengetahuan dan teknologi, ponpes telah melakukan berbagai inovasi untuk meningkatkan peran dan sekaligus memberdayakan potensinya bagi kemaslahatan lingkungannya. Salah satu bentuk adaptasi nyata yang telah dilaksanakan adalah pendirian koperasi di lingkungan ponpes dan dikenal dengan sebutan koperasi pondok pesantren (kopontren)

Keberadaan gerakan koperasi di kalangan pesantren sebenarnya bukanlah cerita baru sebab pendirian koperasi pertama dibumi nusantara adalah Patih Wiriatmadja, seorang muslim yang sadar dan menggunakan dana masjid untuk menggerakkan usaha simpan pinjam dalam menolong jama'ah yang membutuhkan dana. Tumbuhnya gerakan koperasi di kalangan santri merupakan salah satu bentuk perwujudan dari konsep ta'awun (saling menolong), ukhuwah (persaudaraan), tholabul ilmi (menuntut ilmu) dan berbagai aspek ajaran islam lainnya ${ }^{1}$.

Perkembangan koperasi di berbagai dunia cenderung berbeda-beda. Perkembangan koperasi di Negaranegara Eropa Barat dan Jepang misalnya, telah memasuki tahap perkembangan yang sangat maju. Di kedua wilayah ini, koperasi telah berkembang menjadi salah satu pelaku ekonomi yang mampu bersaing secara wajar dengan pelaku-pelaku ekonomi lainnya. Kenyataan yang berlainan kita jumpai di Asia selatan dan Tenggara. Perkembangan koperasi di wilayah ini boleh dikatakan belum mampu bersaing secara sehat dengan badan-

\footnotetext{
${ }^{1}$ Azra Azyumardi, Pesantren, Kontinuitas dan Perubahan, dalam bilik-bilik Pesantren : Sebuah Potret Perjalanan (Jakarta :
} Paramadina, 1997), h.1. 
badan usaha yang lain.

Meskipun demikian, di negeri kita sejarah pengenalan koperasi didorong oleh keyakinan para bapak bangsa untuk mengantar perekonomian Bangsa Indonesia menuju pada suatu kemakmuran dalam kebersamaan dengan semboyan Makmur dalam kebersamaan dan bersama dalam kemakmuran. Kondisi objektif yang hidup dan pengetahuan masyarakat kita hingga tiga dasawarsa setelah kemerdekaan memang menghendaki cara itu. Persoalan pengembangan koperasi di Indonesia sering dicemoh seolah sedang menegakkan benang basah. Pemerintah di Negara-negara berkembang memainkan peran ganda dalam pengembangan koperasi dalam fungsi regulatory dan development. Peran development tidak jarang justru tidak mendewasakan koperasi.

Sejak tahun 1975, Menteri Perdagangan dan Koperasi serta Menteri Pendidikan dan Kebudayaan mengeluarkan putusan bersama Nomor $719 / \mathrm{Kpb} / \mathrm{XII} / 79$ dan Nomor 282a/P/1979 tentang pendirian perkoperasian sekolah, universitas dan lain lain lembaga pendidikan di lingkungan departemen pendidikan dan kebudayaan. Berdasarkan SK bersama tersebut, yang disebut koperasi sekolah atau koperasi siswa adalah koperasi yang anggotanya para siswa atau murid dari suatu sekolah yang berfungsi sebagai wadah untuk mendidik tumbuhnya kesadaran berkoperasi di kalangan siswa.

Pada dasarnya, pendidikan koperasi sekolah menyangkut tiga aspek penting yaitu pengetahuan (kognitif), sikaf (afektif), dan keterampilan (psikomotor). Kegiatan belajar mengajar yang dilakukan di dalam kelas belum mampu mencapai tiga aspek yang diharapkan. Untuk itu, diperlukan suatu wadah yang diharapkan mampu mencapai tujuan tersebut yaitu koperasi sekolah ${ }^{2}$.

Koperasi merupakan kumpulan orang-orang yang bekerja sama memenuhi satu atau lebih kebutuhan ekonomi atau bekerja sama melakukan usaha. Maka dapat dibedakan dengan jelas dari badan-badan usaha atau pelaku kegiatan ekonomi yang lebih mengutamakan modal. Dengan demikian, koperasi sebagai badan usaha mengutamakan faktor manusia dan bekerja atas dasar perikemanusiaan bagi kesejahteraan para anggotanya. Meskipun koperasi merupakan kumpulan dan menjunjung tinggi nilai-nilai kemanusiaan, tetapi koperasi bukanlah badan $\mathrm{amal}^{3}$.

Pada permulaannya, kita mengenal tiga jenis bentuk koperasi yang didasarkan pada bidang-bidang usahanya, yaitu koperasi konsumsi, koperasi produksi, dan koperasi kredit. Selanjutnya terjadi perkembangan usaha yang juga memerlukan perkembangan struktur organisasi, sehingga penjenisan koperasi seperti diatas terasa kurang tepat dan perlu dikembangkan pula. Perkembangan usaha koperasi berlangsung serba cepat dan luas mengikuti kemajuan ekonomi dan tingkat kepentingan/kebutuhan para anggotanya, ini berarti bahwa usaha-usaha dan pelayanan-pelayanannya telah meningkat, walaupun demikian gerak organisasinya tetap bertahan dengan kuat pada sendi-sendi yang khas, yaitu: mengutamakan kesejahteraan para anggotanya dengan gerakan cepat dan tepat ${ }^{4}$.

Bila koperasi mempunyai keunggulan dalam menawarkan produk kepada anggotanya dibanding dengan nonkoperasi, maka dengan sendirinya anggota akan bertransaksi dengan koperasi. Demikian halnya dengan koperasi pondok pesantren mempunyai keunggulan dalam menawarkan alternative investasi kepada investor. Investor akan menanamkan dananya kepada koperasi pondok pesantren. Dengan demikian, bisa dikatakan bahwa anggota dan masyarakat dapat dianggap sebagai konsumen potensial atau investor potensial yang sewaktu-waktu dapat ditarik oleh unit usaha dalam rangka hubungan bisnis ${ }^{5}$. Koperasi mempunyai tujuan yang utama ialah

1. Meningkatkan taraf hidup, saling tolong menolong, dan kesejahteraan anggota-anggotanya,

${ }^{2}$ http://www.asian-spirit. Blogspot.com/2009/12/ Pengenalan Koperasi Sekolah Di Akses 9 November 2012. ${ }^{3}$ Ninik Widiyanti, Koperasi dan Perekonomian Indonesia (Jakarta : Bina Aksara, 1989), h. 3.

${ }^{4}$ G. Kartasapoetra, Praktek Pengelolaan Koperasi (Jakarta: PT. Rineka Cipta, 2005), h. 1.

${ }^{5}$ Hendar, Ekonomi Koperasi (Cet. V ;Jakarta : FE-UI, 1999), h.7. 
2. Menumbuhkan atau meningkatkan apresiasi dan partisipasi siswa terhadap Koperasi sebagai jalur untuk menanamkan dan memupuk jiwa, semangat dan sikap wira Koperasi,

3. Mendidik, menanamkan dan memelihara suatu kesadaran untuk bergotong royong dan setia kawan di antara para siswa,

4. Menunjang pendidikan sekolah ke arah kegiatan yang praktis guna mencapai kebutuhan ekonomi di kalangan siswa,

5. Sebagai ajang pembinaan mental para siswa serta memupuk jiwa kewiraswastaan santri.

Sebuah Koperasi dikatakan berhasil atau sukses jika mampu meningkatkan kesejahteraan anggotanya. Koperasi dapat mensejahterahkan anggotanya karena ia menciptakan nilai tambah dari usaha mereka. Anggota bisa memperoleh nilai tambah jika mereka mau berpartisipasi dalam Koperasinya. Semakin sering anggota berpartisipasi, semakin besar nilai tambah yang mereka dapatkan. Agar Koperasi dapat memberikan nilai tambah kepada anggota, maka Koperasi itu sendiri harus baik kinerjanya. Dalam hal ini, semakin baik kinerja Koperasi, maka semakin besar kemampuan Koperasi mensejahterakan anggotanya. Semakin besar peran Koperasi memperbaiki kesejahteraan anggotanya, semakin tinggi partisipasi mereka dalam kegiatan Koperasi. Jadi, hubungan antara kinerja Koperasi, partisipasi anggota dan kesejahteraan anggota adalah hubungan yang saling mempengaruhi.

Koperasi memiliki kontribusi langsung terhadap kesejahteraan anggotanya karena koperasi mempunyai asas kekeluargaan dan juga fungsi dari koperasi mensejahterakan anggotanya. Koperasi juga memiliki beberapa prinsip diantaranya Prinsip koperasi Keanggotaan bersifat sukarela dan terbuka, pengelolaan dilakukan secara demokratis, pembagian sisa hasil usaha dilakukan secara adil sebanding dengan besarnya jasa usaha masingmasng anggota, pemberian balas jasa yang terbatas terhadap modal, kemandirian dan pendidikan perkoperasian, kerjasama antar koperasi dan fungsi dari koperasi. Untuk memajukannya, harus ada peran aktif para anggotanya karena tanpa adanya peran aktif para anggotanya maka akan tidak berjalan sesuai dengan motto koperasi tersebut ${ }^{6}$.

Koperasi mempunyai fungsi dan peran yaitu :

1. Fungsi koperasi dan peran koperasi untuk membangun dan mengembangkan potensi dan kemampuan ekonomi anggota pada khususnya dan masyarakat pada umumnya dalam meningkatkan kesejahteraan ekonomi dan sosialnya.

2. Fungsi koperasi dan peran koperasi untuk mempertinggi kualitas kehidupan manusia dan masyarakat.

3. Fungsi koperasi dan peran koperasi untuk memperkokoh perekonomian rakyat sebagai dasar kekuatan dan ketahanan perekonomian nasional dengan koperasi sebagai sokogurunya.

4. Fungsi koperasi dan peran koperasi untuk mewujudkan dan mengembangkan perekonomian nasional yang merupakan usaha bersama yang didasarkan asas kekeluargaan dan demokrasi ekonomi

Pada asasnya koperasi bukanlah suatu usaha yang mencari keuntungan semata-mata sebagaimana Allah SWT berfirman dalam QS. Al-Maidah/4 : 2.

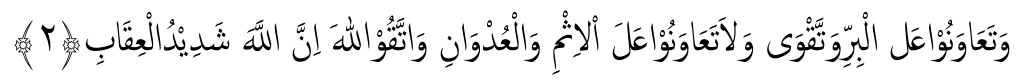

Terjemahannya :

Dan tolong-menolonglah kamu dalam (mengerjakan) kebajikan dan taqwa, dan jangan tolong-menolong dalam berbuat dosa dan pelanggaran. Dan bertakwalah kamu kepada Allah, sesunggubnya Allah amat berat siksa-Nya ${ }^{7}$

${ }^{6}$ Hartaty Robiasih, Peran Aktif Anggota Dalam Mensejabterakan Koperasi.htm.

${ }^{7}$ Departemen Agama Republik Indonesia, Al-Quran dan Terjemahan (Jakarta: Yayasan Peyelenggara Penerjemahan/penafsiran al-quran; 1971), h. 156. 
Koperasi harus memiliki mekanisme pengelolaan yang baik, yang mana dalam kegiatan ekonomi ini santri dan guru ikut serta dalam mengelola proses ekonomi yang sedang berlangsung. Koperasi pesantren memberikan arahan bagi santri dan guru dalam kegiatan ekonomi dan kegiatan itu dijadikan media pendidikan bagi santri. Tujuan ini memberikan arahan bagi guru dan santri tentang cara memilih berbagai alternative yang dapat memuaskan kebutuhan hidup mereka sehari-hari. Yang mana dengan adanya koperasi pesantren, kebutuhan guru dan santri dapat terpenuhi dan koperasi pesantren menyediakan apa yang guru dan santri butuhkan

Dalam koperasi pesantren ini, di samping tujuan yang ekonomis komersial, koperasi harus memperhatikan pula tujuan dan cita-cita sosialnya, terutama bagi anggota-anggotanya. Jadi seorang pengurus koperasi pesantren yang baik harus berusaha dan mampu menjalankan fungsi ekonomi dan fungsi sosial koperasi yang dipimpin di bawah naungan guru dan dijalankan oleh pengurus yang melibatkan santri.

Pondok Pesantren DDI Lilbanat yang berlokasi di kota Parepare sebagai salah satu lembaga pendidikan yang mempunyai sebuah koperasi sebagai salah satu unit usaha. Koperasi pesantren mempunyai peran ganda. Pertama, koperasi pesantren bertujuan untuk memberi kontribusi terhadap peningkatan pondok pesantren dan kedua, koperasi pesantren bertujuan untuk memenuhi kebutuhan guru dan santri dalam kehidupan sehari-hari. Dengan demikian, peran Koperasi Pondok Pesantren DDI Lilbanat sangat menarik untuk diteliti.

\section{B. Dikusi dan Pembahasan}

\section{Manajemen Koperasi Madrasah DDI lil Banat Parepare}

Model struktur organisasi koperasi DDI Lilbanat ini merupakan bidang serta yang menjadi permasalahan dalam menajemen. Sebagai pedoman dalam melaksanakan tugas, harus terdapat garisgaris dasar yang menetapkan pedoman pelaksanaan organisasi dari sesuatu usaha. Organisasi internal dapat diartikan sebagai pembagian tugas dan wewenang yang sesuai dengan fungsi atau unit-unit yang ada dalam organsasi. Susunan orgnisasi koperasi madrasah yang standar diberikan dengan tujuan untuk lebih memahami urian tentang peralatan organisasi koperasi seperti yang telah diuraikan diatas. Skema organisasi madrasah yang tepat terdapat pada halaman berikut ini merupakan susunan standar yang dapat diserasikan sesuai dengan keinginan koperasi madrasah masing-masing daerah.

Mendefinisikan bahwa hubungan yang terjadi di antara penggerak elemen organisasi bersifat formal. Hal ini terjadi dalam rangka pencapaian tujuan yang optimal dan terarah dengan didasari berdayaguna dan bertepat guna.

Unit Usaha yang dikelola oleh Koperasi Pondok Pesantren Al-Badar DDI Parepare terdiri dari empat unit. Keempat unit tersebut adalah :

a. Unit Pertokoan

Unit pertokoan atau Waserda memberikan kontribusi terbesar yaitu 59\% pada SHU kopontren. yaitu Rp. 27.915.000. nilai tersebut secara signifikan melonjak tinngi dibanding penghasilan tahun lalu yaitu sebesar Rp. 19.040.500.

b. Unit Simpan Pinjam

Unit ini memberikan kontribusi 15\% dari total SHU yaitu sebesar Rp. 6.477.000. penerimaan tahun ini terdapat peningkatan dari tahun lalu yang hanya sebesar Rp. 5.920.000. jumlah penerimaan yang kecil pada unit ini karena komitmen pengurus koperasi untuk tetap bertahan pada jasa pinjaman minim yaitu hanya $1 \%$.

c. Unit Fotokopi 
Unit Fotokopy memberikan sumbangsih terbesar kedua setelah Pertokoan yaitu sebesar Rp. 20.055.590. inipun belum maksimal penerimaannya dikarenakan mesin Fotokopy yang kita miliki sering mengalami gangguan.

d. Unit Toko Butik

\section{Upaya Koperasi Pondok Pesantren DDI Lilbanat Dalam Memenuhi Kebutuhan Dan Meningkatkan Kesejahteraan Guru Dan Santri}

Koperasi didirikan berdasarkan surat keptusan bersama antara departemen transmigrasi dan koperasi dengan departemen pendidikan dan kebudayaan taggal 16 juli 1972 nomor 275/SKPTS/mentranskop dan nomor 0102/U/1983. Kemudian diterangkan lebih lanjut dalam surat keputusan menteri tenaga kerja, transmigrasi, dan koperasi nomor 633/SKPTS/men/1974. Menurut surat keputusan tersebut, yang dimaksud dengan koperasi sekolah adalah koperasi yang di dirikan di sekolah-sekolah SD, SMP, SMA, Madrasah dan pesantren.

Landasan pokok dalam perkoperasian indonesia bersumber pada UUD 1945 pasal 33 ayat (1). Pasal ini mengandung cita-cita untuk mengembangkan perekonomian yang berasas kekeluargaan. Peraturan lebih terperinci tertuang dlaam undang-undang nomor 25 tahun 1992. Undang-undang ini berisi pedoman bagi pemerintah dan masyarakat mengenai cara-cara menjalankan koperasi, termasuk koperasi sekolah. Koperasi tidak berbadan hukum. Pengurus dan pengelola koperasi sekolah dilakukan oleh para siswa di bawah bimbingan kepala sekolah dan guru-guru terutama guru bidang studi ekonomi dan koperasi. Tanggung jawab ke luar koperasi sekolah tidak dilakukan oleh pengurus koperasi sekolah, melainkan oleh kepala sekolah. Pembinaan terhadap koperasi sekolah dilaksanakan bersama antara kantor menteri negara koperasi usaha kecil dan menenga, serta departemen pendidikan nasional. Koperasi sekolah tidak berbadan hukum seperti koperasi-koperasi lainnya karena siswa atau pelajar pada umumnya belum mampu melakukan tindakan hukum.

Dalam pengertian ekonomi pendapatan dapat dibentuk pendapatan nominal dan pendapatan riil. Pendapatan nominal adalah pendapatan seseorang yang dapat diukur dalam jumlah barang dan jasa pemenuhan kebutuhan yang dapat dibeli dengan membelanjakan pendapatan nominalnya (uangnya). Apabila pendapatan nominal seseorang meningkat sementara harga barang atau jasa tetap (tidak naik), maka orang tersebut akan lebih mampu membeli barang untuk memenuhi kebutuhannya, yang berarti tingkat kesejahteraan meningkat pula. Dalam kondisi seperti di indonesia, di mana pendekatan pembinaan dan pengembangan koperasi dengan sejumlah anggota yang kurang mempunyai hubungan ekonomi satu sama lain.

Status koperasi sekolah yang dibentuk di sekolah merupakan koperasi terdaftar, tetapi mendapat pengakuan sebagai perkumpulan koperasi. Pendirian koperasi sekolah diharapkan menjadi sarana bagi pelajar untuk belajar melakukan usaha kecil-kecilan, mengembangkan kemapuan berorganisasi, mendorong kebiasaan untuk berinovasi, belajar menyelesaikan masalah dan sebagainya. Untuk itu dalam mendirikan koperasi sekolah, diperlukan pertimbangan-pertimbangan agar selaras dengan apa yang diharapkan. Dalam undang-undang nomor 25 tahun 1992 tentang pokok-pokok perkoperasian pasal 3 disebutkan bahwa koperasi sekolah betujuan untuk memajukan kesejahteraan anggota (guru dan siswa), pada khusunya dan masyarakat pada umumnya serta ikut membangun tatanan perekonomian nasional dalam rangka mewujudkan masyarakat yang maju, adil dan makmur, berlandaskan pancasila dan UUD tujuan koperasi sekolah adalah bersiafat umum. Karena itu, setiap koperasi perlu menjabarkannya kedalam bentuk tujuan yang lebih operasional bagi koperasi sebagai badan usaha. Tujuan yang jelas dapat dioperasionalkan akan memudahkan pihak manajemen dalam mengelola koperasi pada kasus anggota (guru dan siswa), juga bertindak sebagai pemilik, pelanggan dan 
permodal akan dapat lebih mudah melakukan pengawasan terhadap proses pencapaian tujuan koperasi sehingga penyimpangan dari tujuan tersebut akan dapat lebih cepat diketahui. Dalam tujuan tersebut dikatakan bahwa koperasi sekolah memajukan kesejahteraan guru dan siswa pada khususnya dan masyarakat pada umumnya. Di mana koperasi dalam meningkatkan kesejateraan guru dan siswa adalah menjadi program utama koperasi sekolah melalui pelayanan usaha. Jadi, dengan utama pelayanan anggota (guru dan siswa) merupakan prioritas utama dibandingkan dengan masyarakat umum. ${ }^{8}$

Tujuan koperasai sekolah adalah memajukan kesejahteraan anggota pada khususnya dan masyarakat pada umumnya, serta ikut membangun tata perekonomian nasional dalam rangka mewujudkan masyarakat yang adil dan makmur. Sedangkan pembentukan koperasi sekolah di kalangan siswa dilaksanakan dalam rangka menunjang pendidikan siswa dan latihan berkoperasi. Dengan demikian, tujuan pembentukannya tidak terlepas dari tujuan pendidikan dan program pemerintah dalam menanamkan kesadaran berkoperasi sejak dini.

Bapak Syaiful Mahsan S.Pt. M.Si selaku ketua koperasi pondok pesantren DDI Lilbanat Parepare mengungkapkan bahwa Upaya-Upaya umum koperasi Pondok pesantren DDI Lilbanat untuk memenuhi kebutuhan dan meningkatkan kesejahteraan guru dan santri yaitu;

a. Memperbaiki Kegiatan koperasi

b. Pengelolaan unit usaha koperasi

c. Pemberlakuan piket di koperasi

d. manajemen koperasi maupun Rapat anggota koperasi

e. Memotivasi anggota untuk aktif membayar simpanan wajib dan simpanan dan Tabakop

f. Menggunakan Kartu Anggota untuk memudahkan anggota dan karyawan dalam bertransaksi. ${ }^{9}$

Sehubungan dengan Perkataan Bapak Mahsan di atas, Menurut Ibu HJ. ST. Awaliyah, S.Ag selaku bendahara koperasi pondok pesantren DDI Lilbanat menambahkan dengan mengatakan bahwa; upaya-upaya yang dilakukan untuk memenuhi kebutuhan dan meningkatkan kesejahteraan guru dan santri atau anggota koperasi pondok pesantren yaitu:

Upaya dalam hal Manajemen

a. Menyusun pembagian kerja pengurus

b. Melakukan Rapat Triwulan dengan mengundang seluruh pengurus dan anggota

c. Setiap transaksi/penandatanganan tidak boleh dilakukan tanpa sepengetahuan/rekomendasi mandat ketua

d. Arus jalannya keuangan harus melalui bendahara Surat-surat yang masuk harus didesposisi ketua baru diarsipkan

e. Meningkatkan rasa ukhuwah dan kerjasama antar pengurus dan badan pengawas

f. Mengutamakan disiplin dan profesionalisme kerja

g. Mengupayakan peningkatan skill/pengetahuan pengurus dengan mengikutsertakan pengurus pelatihan teknis.

Upaya Dalam hal bidang unit Usahanya

a. Usaha Pertokoan

1) Menyediakan barang kebutuhan sehari-hari kepada anggota dengan harga serendah mungkin

2) Melakukan pembenahan ruang dari toko klasik menjadi bentuk swalayan

${ }^{8}$ Arifin Sitio Dan Holomoan Tamban, Koperasi : Teori Dan Praktek (Jakarta : PT. Gelora Aksara Pratam).

9Saiful Mahsan, Ketua Koperasi Pondok Pesantren DDI Lilbanat Parepare, Wawancara, 28 Agustus 2017. 
3) Menertibkan pencatatan Penjualan dan Pembelian Barang baik anggota maupun bukan anggota

4) Merintis berdirinya Kantin Pondok yang permanen

b. Jasa Simpan Pinjam

1) Menyediakan dana pinjaman dengan angsuran setiap bulan dalam jangka waktu maksimal 20 bulan.

2) Anggota yang melakukan pinjaman diberikan kartu kontrol

3) Melakukan penagihan kepada anggota yang ansurannya menunggak

4) Menambah batas maksimum pinjaman anggota

5) Membuka program pembiayaan untuk barang

c. Warung telekomunikasi dan Internet

1) Memaksimalkan pemanfaatkan sarana warnet dengan program voucher baik dalam ruangan maupun via hospot

2) Melakukan kerjasama untuk membuat lomba website/blog dan lomba lain via email

3) Melakukan penjualan aksesosi computer, pulsa dan Hp

d. Unit Fotokopi

Unit Fotokopi telah berjalan selama tiga tahun namun masih dibutuhkan strategi untuk mengoptimalkan usaha tersebut dengan menambah pelanggan dan mempertimbangkan persainagan harga. Untuk meningkatkan menerimaan pada unit ini akan dibuka toko buku dan ATK. Perlu adanya penambahan mesin fotokopy yang baru.

Upaya Dalam hal Administrasinya

Sejak pemindahan lokasi Unit usaha Pertokoan ini ke lokasi sekarang jumlah penerimaan menjadi meningkat hal ini patut kita syukuri dan merupakan bukti pelayanan anggota pada unit ini makin meningkat. Harga barang di toko sudah sangat kompetitif (murah). Terbukti dengan jumlah penerimaan yang mencapai $56 \%$ dari total penerimaan Kopontren ${ }^{10}$.

Jenis usaha ini sangat potensial untuk dikembangkan, mengingat banyaknya harian santri, kebutuhan alat-alat tulis kantor. Untuk itu koperasi pondok pesantren DDI Lilbanat membuka toko di lingkungan pondok pesantren DDI Lilbanat membuka toko dilingkungan DDI Lilbanat agar seluruh kebutuhan para santri dan kebutuhan ATK dapat tercukupi tanpa harus belanja di luar pondok pesantren DDI Lilbanat.

Jumlah penerimaan pada unit simpan pinjam meningkat dari tahun sebelumnya. Peningkatan tersebut diiringi dengan patisipasi anggota memanfaatkan USP semakin tinggi. Banyaknya dana yang tersimpan di Kas Bendahara dan Bank itu merupakan potensi yang besar untuk mengembangkan unit ini. Di samping itu, patut dimaklumi pengelola USP untuk tetap selektif dalam memberikan pinjaman untuk menghindari Meningkatnya Piutang Tunggakan dan Piutang Tidak Lancar (kredit Macet)

Simpan pinjam ini dikelola secara mandiri dan asa saling tolong menolong antar sesama pegawai. Mengingat banyaknya minat dari pegawai para anggota untuk mengajukan pembiayaan, sedangkan modal sendiri yang bersumber pada simpanan pokok, simpanan wajib dan simpanan sukarela masih sangat terbatas.

${ }^{10}$ HJ. ST. Awaliyah, Bendahara Koperasi Pondok Pesantren DDI Lilbanat Parepare, Wawancara, 25 Agustus 2017. 
Tahun ini penerimaan Unit Wartel tidak ada, hal ini terjadi karena unit ini tidak berjalan. Omset yang sudah jauh menurut selama tiga tahun berturut-turut. Perlu dipertimbangkan untuk mengevaluasi unit tersebut. Dibutuhkan inovasi dan upaya untuk menggalah santri mengunakan jasa usaha Warnet tersebut.

Santri, guru, karyawan pondok pesantren DDI Lilbanat berasal dari berbagai daerah di indonesia. Tentunya keadaan ini sangat membutuhkan media untuk berkomunikasi mutlak di perlukan untuk memberikan sarana komunikasi bagi para santri dengan orang tua/wali santri. Untuk menunjang kegiatan pembelajaran para santri, maka koperasi pondok pesantren DDI Lilbanat yang bertujuan agar para santri tidak kesulitan dalam mencari materi yang dibutuhkan tanpa keluar dari area pondok pesantren. Warnet ini juga merupakan salah satu tempat yang digunakan santri untuk kegiatan praktek dalam membuat website, blog dan jaringan internet.

Warnet yang dikelola oleh koperasi pondok pesantren DDI Lilbanat ini dipatok dengan harga 4000,00 per jam yang digunakan khusus masyarakat di dalam pondok pesantren DDI Lilbanat khususnya para santri dan guru. Dengan adanya fasilitas warnet ini santri bisa mencari pengetahuan yang berkaitan dengan mata pelajaran.

Pada tahun buku 2007 unit Butik ini menjadi unit unggulan dalam penerimaan income koppontren kita. Tetapi dari tahun ke tahun terlihat adanya penurunan Pendapatan pada unit ini yang sangat drastis. Walaupun tahun buku 2012 terdapat peningkatan namun tahun buku 2013 ini sangat turun bahkan tercatat minus Rp. 7.024.500 pada SHU kotor. Hal ini telihat adanya jumlah stok barang yang sangat berkurang namun tidak diimbangi dengan pendapatan yang bertambah. Sehingga terjadi minus.

Berdasarkan kegiatan usaha koperasi pondok pesantren DDI Lilbanat di atas, maka dapat diketahui bahwa koperasi pondok pesantren (koppontren) DDI Lilbanat yang bergerak dalam berbagai usaha atau bisa dikenal dengan sebutan koperasi serba usaha, usaha koppontren DDI Lilbanat ini dapat bertambah. Usaha-usaha inilah yang membantu koperasi ini memiliki modal tambahan yang nantinya dapat berguna sebagai modal cadangan atau modal simpanan, yang dapat digunakan atau untuk mengantisipasi apabila dalam kegiatan koperasi mengalami kekurangan.

Bidang Keuangan

Keadaan keuangan sebagai berikut:

Setelah diperiksa dan diteliti maka uang yang ada sekarang ini total

$=$ Rp.142.077.500

Angka ini patut disyukuri karena menandakan banyaknya dana yang dapat dijadikan modal usaha. Perlu dipikirkan untuk menggunakannya secara maksimal sehingga tidak mengendap saja. ${ }^{11}$

Koperasi pondok pesantren DDI Lilabanat didirikan pertama kali dengan modal yang diperoleh hanya dari simpanan pokok dan simpanan wajib saja. Usaha-usaha yang dikelola oleh koppontren ini masih terbatas pada penyediaan alat-alat tulis kantor dan penyediaan kebutuhan pokok para anggota pondok pesantren itu sendiri seiring perkembangan zaman para pengurus anggota koppontren terus mencoba memajukan koppontren tersebut dengan membuat usaha-usaha baru tanpa harus meninggalkan usaha yang lama ${ }^{12}$.

${ }^{11}$ Laporan RAT (Rapat Anggota Tahunan),2014, Koppontren DDI Lilbanat.

${ }^{12}$ Laporan RAT (Rapat Anggota Tahunan),2014, Koppontren DDI Lilbanat. 


\section{Upaya Peningkatan Kesejahteraan}

Koperasi sekolah adalah koperasi yang anggota-anggotanya terdiri atas siswa-siswa sekolah. Anggota koperasi sekolah disesuaikan dengan tempat organisasi itu berada. Jika berada di lingkungan pendidikan dasar maka anggotanya adalah siswa sekolah dasar, demikian pula pada tingkat pendidikan menengah dan atas. Koperasi adalah badan usaha yang beranggotakan orang atau badan hukum denagn melandaskan kegiatannya berdasar prinsip koperasi sekaligus sebagai gerakan ekonomi rakyat yang berdasarkan atas asas kekeluargaan.

Dalam undang-undang No. 25 tahun 1992 tentang pokok-pokok perkoperasian pasal 3 Disebutkan bahwa koperasi sekolah bertujuan untuk memajukan kesejahteraan anggota (guru dan siswa), pada khususnya dan masyarakat pada umumnya, serta ikut membangun tatanan perekonomian nasional dalam rangka mewujudkan masyarakat yang maju, adil, dan makmur, berdasarkan pancasila dan undang-undang 1945. Fungsi koperasi untuk indonesia tertuang dalam pasal 4 UU No. 25 tahun 1992 tentang perkoperasian yaitu; membangun dan mengembangkan potensi dan kemampuan ekonomi anggota (guru dan siswa), pada khususnya dan masyarakat pada umumnya untuk meningkatkan kesejahteraan ekonomi dan sosia. Berperan serta secara aktif dalam upaya mempertinggi kualitas kehidupan manusia dan masyarat. Memperkokoh perekonomian rakyat sebagai dasar kekuatan dan ketahanan perekonomian nasional dengan koperasi sebagai soko gurunya. Berusaha untuk mewujudkan dan mengembangkan perekonomian nasional yang merupakan usaha bersama berdasarkan asas kekeluargaan dan demokrasi ekonomi. ${ }^{13}$ Selanjutkan dalam pasal 33 UUD 1945 disebutkan bahwa dasar demokrasi ekonomi produksi dikerjakan oleh semua, untuk semua dibawah pimpinan anggota (pengurus). Kemakmuran gurulah yang diutamakan. ${ }^{14}$

Tujuan koperasi sekolah adalah bersifat umum. Karena itu, setiap koperasi perlu menjabarkannya kedalam bentuk tujuan yang lebih operasional bagi koperasi sebagai badan usaha. Tujuan yang jelas dapat di operasionalkan akan memudahkan pihak manajemen dalam mengelola koperasi pada kasus anggota (guru dan santri), juga bertindak sebagai pemilik, pelanggan dan pemodal akan dapat lebih mudah melakukan pengawasan terhadap proses pencapaian tujuan koperasi, sehingga penyimpangan dari tujuan tersebut akan dapat lebih cepat diketahui. Dalam tujuan tujuan tersebut dikatakan bahwa koperasi sekolah memajukan kesejahteraan guru dan siswa pada khususnya dan masyarakat pada umumnya.

Koperasi didirikan bertujuan untuk memperbaiki kehidupan ekonomi dan sosial anggotanya, mmisalnya melalui kopersi konsumsi meraka dapat menigkatkan penghasilan taraf hidup mereka, karena mereka akan memperolah harga barang-barang yang murah sekaligus dapat bersosialisasi dengan anggota lain melalui sosialisasi mereka dapat salig berbagi untuk memecahkan masalah ekonomi yang mereka hadapi. Begitu pula koperasi sekolah yang beranggotakan guru, pegawai sekolah dan siswa, mereka dapat memenuhi kebutuhan konominya melalui koperasi yang mereka usahakan secara bersama. Dikelolah secara bersama, dan diawasi bersama untuk kesejateraan bersama.

Fungsi dari koperasi pada pondok pesantren DDI Lilbanat yaitu:

a. Membangun dan mengembangkan potensi dan kemampuan ekonomi anggota (guru dan santri), pada khususnya dan masyarakat pada umumnya untuk meningkatkan kesejahteraan ekonomi dan sosial.

b. Berperan secara aktif dalam upaya mempertinggi kualitas kehidupan manusia dan masyarakat.

\footnotetext{
${ }^{13}$ Aripin Sitio Dan Halomoan Tamban, Koperasi: Teori Dan Praktek (Jakarta: PT. Galora Aksara Pratam) .

${ }^{14}$ Michael Todaro, Ekonomi Pembangunan (Jakarta: Air Langga, 1992), h. 62.
} 
c. Memperkokoh perekonomian rakyat sebagai dasar kekuatan dan ketahanan perekonomian nasioanal dengan koperasi sebagai soko gurunya.

d. Menumbuhkan kesadaran berkoperasi di kalangan santri.

e. Membina rasa tanggung jawab, disiplin, setia kawan, dan jiwa koperasi.

f. Meningkatkan pengetahuan dan keterampilan berkoperasi, agar kelak berguna di masyarakat.

g. Membantu kebutuhan santri serta mengembangkan kesejahteraan santri di dalam dan luar sekolah.

h. Mendidik dan menanamkan kesadaran hidup gotong royong dan setia kawan serta jiwa demokrasi di antara para santri.

i. Membantu dan melayani pemenuhan kebutuhan ekonomi para santri melalui pengembangan berbagai kegiatan usaha. ${ }^{15}$

Dalam mengembangkan koperasi sekolah secara langsung santri dilatih, di berdayakan melalui kegiatan usaha yang dilandasi sifat kebersamaan, kejujuran, kedisiplin, demokrasi, kemandirian, dan tanggung jawab sehingga secara tidak langsung membantu mempercepat pencapaian tujuan pendidikan karakter. Oleh karena itu, jika keberadaan koperasi dikembangkan maka secara tidak langsung membantu mengembangkan pendidikan karakter dan kewirausahaan.

Pengembangan kewirausahaan sekolah berbasis kreativitas dan inovasi dapat memberikan pengalaman belajar yang berharga bagi santri. Pemanfaatan koperasi dapat dijadikan sebagai tempat praktik langsung santri dalam mengasah keterampilan dan keahliannya. Pengelolaan koperasi sekolah selain sebagai media pembelajaran juga dapat memberikan sumbangsih dalam menambah penghasilan sekolah dan membantu membangun perekonomian masyarakat.

Selanjutnya karena pengembangan jiwa koperasi tidak dapat dilakukan secara instant. Sikap mental koperasi membutuhkan sentuhan nyata (real touch), untuk mengasah potensi segala internal yang ada pada diri masing-masing orang agar menjadi terlatih. Pengembangan jiwa koperasi juga sesuai dengan dengan tujuan pendirian koperasi. Pada saat koperasi sekolah benar-benar dirasakan santri sebagai wadah yang dapat menggembleng diri mereka dalam menghadapi masa depan maka minat entrepreneur juga dapat muncul pada saat santri dilatih dalam wadah koperasi sekolah.

Perkembangan kegiatan ekonomi melalui koppontren DDI Lilbanat ini mendorong para anggota atau guru dan santri dalam menampung aktivitas, tempat memecahkan masalah khususnya dalam perekonomian. Tujuan dierikan pinjaman kepada anggota agar anggota dapat hidup makmur serba kecukupan dan meningkatkan kesejahteraan keluarga dari anggota koppontren DDI Lilbanat. Salah satunya usaha koppontren dalam mewujudkan tujuannya adalah dengan memberikan modal kepada anggota yang sedang membutuhkan. Koperasi sekolah sangat membantu bagi para santri untuk mengembangkan potensi dalam bidang ekonomi dan sebagai latihan bertanggung jawab dan kemandirian siswa.

Pendirian koperasi sekolah diharapkan menjadi sarana bagi pelajar untuk santri melakukan usaha kecil-kecilan, mengembangkan kemampuan berorganisasi, mendorong kebiasaan untuk berinovasi, belajar menyelesaikan masalah, dan sebagainya. Untuk itu dalam mendirikan koperasi sekolah diperlukan pertimbangan agar yang diharapkan. Untuk itu dalam mendirikan koperasi sekolah, diperlukan pertimbangan-pertimbangan agar selaras dengan apa yang diharapkan.

Salah satu fungsi koperasi pondok pesantren ini adalah agar para santri tumbuh jiwa setia kawan, saling menghargai, kesamaan derajat dan gotong royong antar sesamanya dan menumbuhkan serta mengasah demokrasi, kreativitas, kemampuan, pengetahuan dan lain sebagainya. Di samping itu,

${ }^{15}$ Syaiful Mahsan, Ketua Koperasi Pondok Pesantren DDI Lilbanat Ujung Lare Parepare, Wawancara, 25 Agustus 2017. 
koperasi sekolah dapat memiliki peran dalam memasyarakatkan koperasi melalui pendidikan ekonomi dan koperasi sekolah. Salah satu tujuan yang diharapkan adalah para siswa yang telah lulus nanti dapat mendirikan koperasi ataupun mewarisi nilai-nilai karakter dalam kegiatan berkoperasi. Keberadaan koperasi sekolah dapat digunakan sebagai wahana pembelajaran berkoperasi dan berusaha untuk mengasah dan mengembangkan potensi kewirausahaan. Sehigga nantinya memiliki alternatif menjadi wirausaha mandiri atau sebagai pencari kerja. Alternatif tersebut dimungkinkan sebab koperasi sekolah sebagai badan usaha memberikan manfaat ganda terhadap para santri sebagai anggota koperasi sekolah. Pertama, santri dapat secara langsung mengenal, melihat, dan mempraktekkan teori dalam kehidupan nyata koperasi sekolah. Kedua, koperasi sekolah digunakan sebagai wahana pembelajaran, sehingga santri memperoleh pengetahuan dan keterampilan berusaha yang bermanfaat untuk menumbuhkan jiwa kewirausahaan yang berakibat tumbuhnya keberanian untuk berusaha secara mandiri sehingga mampu menciftakan lapangan kerja dan mengurangi pengangguran dan kemiskinan. Disinilah perlunya upaya penanaman pendidikan karakter dalam diri setiap siswa.

Fungsi Koperasi Sekolah Sebagai Wahana Pembelajaran. Koperasi Siswa yang anggotanya para seluruh siswa dari suatu sekolah, yang fungsinya sebagai wadah untuk belajar dan menumbuhkan tumbuhnya kesadaran berkoperasi di kalangan siswa sebagai anggota dan pengurus. Koperasi sekolah mempunyai nilai dan potensi strategis untuk meminimalisir masalah pengangguran karena skill yang tidak memadai dalam kewirausahaan atau entrepreneur.

Menurut Ibu ST. Awaliyah selaku bendahara koperasi pondok pesantren DDI Lilbanat mengatakan bahwa; koperasi mempunyai beberapa potensi untuk meningkatkan kesejahteraan diantaranya yaitu:

a. Koperasi pesantren sebagai wahana pembelajaran sehingga memiliki alternatif bagi kepentingan di masa depan.

b. Potensi peningkatan kualitas SDM karena kopsek sebagai sarana pembelajaran berkoperasi dan mengasah potensi kewirausahaan sehingga tersedianya wahana proses pembelajaran memiliki alternatif menjadi mandiri sehingga dapat meningkatkan kualitas sumber daya manusia.

c. Potensi sebagai wahana pembelajaran karena para santri mengenal dan mempraktekkan sendiri aktivitas-aktivitas pengelolaan transaksi atau berusaha seperti mencatat, membukukan, melayani pelanggan, menerima barang, mengelola barang serta berbagai aktivitas lainnya. ${ }^{16}$

Kondisi koperasi pondok pesantren pada umumnya kurang menggembirakan, maka peran guru ekonomi sangat diperlukan untuk menjadi pengerak, pembimbing tumbuh kembangnya pembelajaran koperasi. Koperasi sekolah sebagai wahana dalam pembelajaran. Koperasi Sekolah adalah koperasi yang berada dalam lingkungan sekolah yang anggotanya adalah siswa dari sekolah tersebut yang dapat melakukan kegiatan ekonomi tanpa badan hukum. Koperasi sekolah merupakan wahana pembelajaran ekstrakulikuler yang kegiatannya terlepas dari kegiatan belajar, dan hanya merupakan kegiatan tambahan sekolah yang mempunyai ilmu dan manfaat yang dangat bagus. Bisa saja, para siswa yang telah lulus nanti dapat mendirikan koperasi.

Koperasi pondok pesantren DDI Lilbanat ini mempunyai fungsi sebagai proses pemberdayaan baik dilihat dari hubungan internal maupun eksternal. Secara internal, koperasi pondok pesantren DDI Lilbanat berusaha untuk mendidik santri dan anggota daerah pondok pesantren agar mereka mempunyai bekal keterampilan dengan memberikan pelatiha-pelatihan melaui kegiatan workshop, pembinaan keterampilan pegawai dalam pelaksanaan tugas yang dilakukan sesuai dengan agenda

${ }^{16}$ Hj. St. Awaliyah, Bendahara Kopersi Pondok Pesantren Ddi Lilbanat Ujung Lare Parepare, Wawancara, 25 Agustus 2017. 
koperasi. Secara eksternal, untuk mengenalkan koperasi dalam kalangan santri dan guru atau masyarakat sekitar Pondok pesantren dalam mempermudah pemasarannya. Sebuah koperasi yang kedudukannya berada dilingkungan pondok pesantren mempunyai nilai strategis dalam pengembangan kehidupan ekonomi di pondok pesantren DDI Lilbanat. Pada posisi tertentu, koperasi pondok pesantren akan dapat menopang keberlangsungan aktivitas santri, ustadz dan kyai di pesantren. Sedangkan sistem yang paling cocok untuk diterapkan pada koperasi pondok pesantren dapat menggunakan prinsip sayariah sebagai acuannya. Dalam hal ini, transaksi yang dikelola koperasi pondok pesantren DDI Lilbanat dapat disesuaikan dengan akad (kontrak) yang disepakati. Sesuai dengan ketentuan yang berlaku mengani perkoperasian di indonesia, kewenangan yang dimiliki oleh koperasi dapat berupa kegiatan penghimpunan dan melalui simpanan pokok, simpanan wajib dan simpanan manasuka, serta kegiatan penyaluran dana kepada anggotanya.

Menurut Bapak Syaiful Mahsan yang mengatakan bahwa; Terdapat beberapa faktor pendorong koperasi dalam meningkatkan kesejahteraan anggota koperasi Pondok pesantren DDI Lilbanat adalah sebagai berikut :

a. Adanya peningkatan pengetahuan dan keterampilan bagi anggota/pegawai.

b. Anggota atau pegawai merasa puas dengan pelayanan yang diberikan oleh koperasi pondok pesantren DDI Lilbanat dalam pemenuhan kebutuhan. ${ }^{17}$

Dalam hal peningkatan keterampilan, disini anggota atau pegawai dituntut untuk bisa masarkan produk, dan penggunaan teknologi sesuai dengan kegiatan usahanya, serta memproduksi barang dan jasa.

Dalam hal ini koperasi mempunyai yang lain karena koperasi dapat memberikan kemungkinan pengenalan teknologi baru malalui kehematan dengan mendapatkan informasi yang lagsung tersedia bagi setiap anggota yang memerlukannya.

Kesemuanya itu dapat diperoleh bagi setiap individu anggotanya yang telah memutuskan menjadi anggota koperasi. Mereka akan lebih cepat memperoleh informasi secara cepat misalnya melalui penyuluhan-penyuluhan berkaitan dengan koperasi atau kewirausahaan. Disini mereka akan tau potensi SDA yang ada disekililing kita yang nantinya bisa dikembangkan sesuai dengan bakat yang dimiliki dan atau bagaiaman caranya dalam mengembangkan potensi SDA yang ada tersebut. Hal ini yang mendorong dalam peningkatan kesejahteraan anggota di bidang keterampilan. Dengan demikian sepanjang koperasi dapat menghasilkan kemanfaatan tersebut abgi anggotanya maka akan mendorong orang untuk berkoperasi karena dinilai bermanfaat.

Umumnya koperasi memperluas area usahanya di bidang produksi yang selian memberi keuntungan juga menambah pendapatan demi kesejahteraan anggotanya. Ini berbeda sekali dengan koperasi pondok pesantren DDI Lilbanat, di mana koperasi ini berusaha untuk semua kebutuhan anggota atau pegawai demi kesejahteraan bersama tercukupi, selain untuk memenuhi kebutuhan pokok, juga membantu orang tua yang kesulitan biaya pendidikan untuk anak-anaknya. Dengan adanya pelayanan koperasi yang maksimal ini, maka akan memberikan konstribusi yang berarti, dalam menopang kebutuhan ekonomi anggotanya. Mereka dapat menggunakan jasa keuangan koperasi, tanpa harus berbelit-belit dan tidak harus menggadaikan surat-surat penting. Oleh karena itu koperasi pondok pesantren DDI Lilbanat dalam memberikan pelayanan yang baik kepada masyarakat di pondok pesantren.

${ }^{17}$ Syaiful Mahsan, Ketua Koperasi Pondok Pesantren DDI Lilbanat Ujung Lare Parepare, Wawancara, 25 Agustus 2017. 
Sesuai dengan visi dan misi dan tujuan dari koperasi pondok pesantren tersebut yang mempunyai komitmen untuk mensejahterakan anggota baik anggota yang ada di dalam pondok pesantren DDI Lilbanat maupun anggota diluar pondok pesantren DDI Lilbanat. Koperasi pondok pesantren DDI Lilbanat merupakan salah satu organisasi pemberdayaan ekonomi yang berada di pondok pesantren dalam upaya meningkatkan kesejahteraan, baik dilingkungan pesantren maupun di lingkungan masyarakat luar, dengan mengoptimalkan penggunaan sumber daya yang ada pada lingkungan sekitar pesantren sehingga memberikan rangsangan terbentuknya usaha-usaha baru yang menguntungkan. Usaha-usaha yang telah terbentuk yang dikelola pesantren dan dapat memberikan keuntungan ekonomi pada masyarakat dan pondok pesantren. Melalui koperasi, aktivitas perekonomian pondok pesantren DDI Lilbanat bisa terwadahi. Adanya wadah koperasi ini diharapkan sebagai tempat untuk mengembangkan diri, kerjasama, dan menambah keterampilan dalam berbagai hal serta memperluas pergaulan. Sehingga organisasi ini berdampak positif bagi anggotanya misalnya menambah pengetahuan dibidang kewirausahaan yang dapat berguna dalam kehidupan sehari-hari.

Pengembangan usaha koperasi pondok pesantren DDI Lilbanat mengalami kemajuan, hal ini dibuktikan dengan bertambahnya kegiatan usaha yang dikembangkan oleh koperasi pondok pesantren DDI Lilbanat. Salah satu konstribusi koperasi pondok pesantren DDI Lilbanat dalam meningkatkan kesejahteraan anggota di koperasi pondok pesantren DDI Lilbanat yang bersifat material (ekonomi).

Membangun dan mengembangkan potensi serta kemampuan ekonomi anggota pada khususnya dan masyarakat pada umumnya untuk mensejahterakan ekonomi dan sosialnya. Berperan serta aktif dalam upaya mempertinggi kualitas kehidupan manusia dan masyarakat. Memeperkokoh perekonomian rakyat sebagai kekuatan dan ketahanan perekonomian nasional dengan koperasi sebagai soko gurunya.

Peningkatan kesejahteraan tidak hanya dirasakan oleh anggota guru saja, tetapi juga dirasakan oleh para santri melalui kegiatan pengembangan kewirausahaan santri, misalnya saja latihan menjaga kantin di saat istirahat. Pelatihan ini bertujuan untuk memberikan skill pada santri untuk melakukan usaha kongkrit di bidang kewirausahawan.

Aspek-aspek yang sangat mendesak saat ini adalah proses pembangunan yaitu proses multidimensi yang menyangkut perubahan penting dalam struktur sosial, sikap guru lembaga nasional. Dalam melaksanakan pembangunan tersebut perlu adanya peningkatan peranan guru untuk mengerakkan dana dan daya masyarakat baik sumberdaya manusia maupun alam.

Koperasi dalam islam adalah lembaga usaha yang dinilai cocok untuk meberdayakan rakyat kecil. Nilai-nilai koperasi juga mulai sperti keadilan, kebersamaan, kekeluargaan, dan kesejateraan bersama. Lembaga ini adalah wadah kemitraan, kerjasama, kekeluargaan, dan kebersamaan usaha yang sehat, dan halal. Seperti dalam QS. An-Nisaa/4 : 12 yang berbunyi :

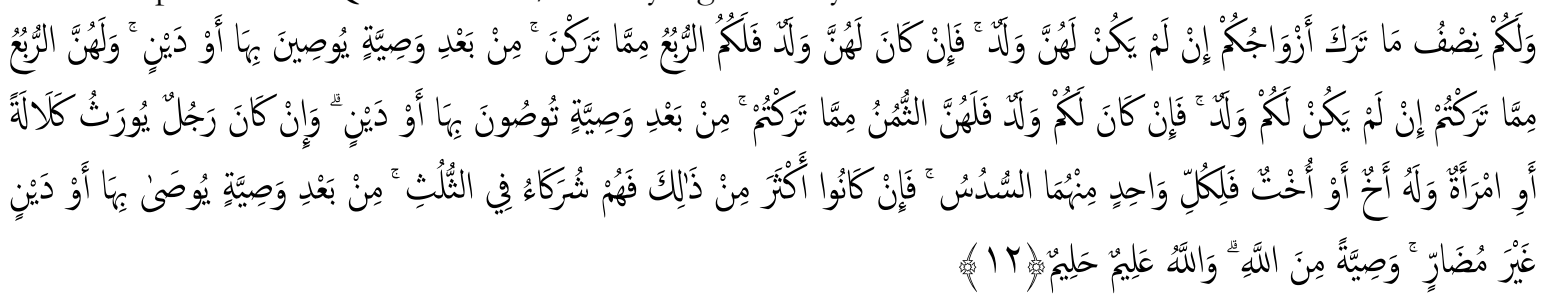

Terjemahannya :

"Dan bagimu (suami-suami) seperdua dari harta yang ditinggalkan oleb isteri-isterimu, jika mereka tidak mempunyai anak. Jika isteri-isterimu itu mempunyai anak, maka kamu mendapat seperempat dari harta yang ditinggalkannya sesudah dipenubi wasiat yang mereka buat atau (dan) seduah dibayar butangnya. Para isteri 
memperoleh seperempat harta yang kamu tinggalkan jika kamu tidak mempunyai anak. Jika kamu mempunyai anak, maka para isteri memperoleh seperdelapan dari harta yang kamu tinggalkan sesudah dipenubi wasiat yang kamu buat atau (dan) sesudah dibayar hutang-hutangmu. Jika seseorang mati, baik. laki-laki maupun perempuan yang tidak meninggalkan ayah dan tidak meninggalkan anak, tetapi mempunyai seorang saudara laki-laki (seibu saja) atau seorang saudara perempuan (seibu saja), maka bagi masing-masing dari kedua jenis saudara itu seperenam harta. Tetapi jika saudara-saudara seibu itu lebih dari seorang, maka mereka bersekutu dalam yang sepertiga itu, sesudah dipenubi wasiat yang dibuat olehnya atau sesudab dibayar hutangnya dengan tidak memberi mudharat (kepada abli waris). (Allah menetapkan yang demikian itu sebagai) syari'at yang benar-benar dari Allah, dan Allah Maha Mengetahui lagi Maha Penyantun". ${ }^{18}$

Adapun fungsi dan peran koperasi islam antara lain :

a. Memangun dan mengembangkan potensi dan kemampuan anggota pada khususnya, dan masyarakat pada umumnya guna meningkatkan kesejahteraan sosial ekonomi.

b. Memperkuat kualitas sumber daya insani anggota, agar menjadi lebih amanah, propesional (fatonah, konsisten, dan konsekuen (istiqomah)di dalam menerapkan prinsip.

c. Berusaha untuk mewujudkan dan mengembangkan perkonomian nasional yang merupakan usaha bersama berdasarkan azas kekeluargaan dan demokrasi ekonomi.

d. Sebagai mediator antara menyandang dana dengan penggunaan dana, sehingga tercapai optimalisasi pemanfaatan harta.

e. Menguatkan kelompok-kelompokanggota

f. menumbuhkan dan mengembangkan usaha-usaha produktif anggota.

Dalam QS. Al-Baqarah/2 : 283 yang berbunyi:

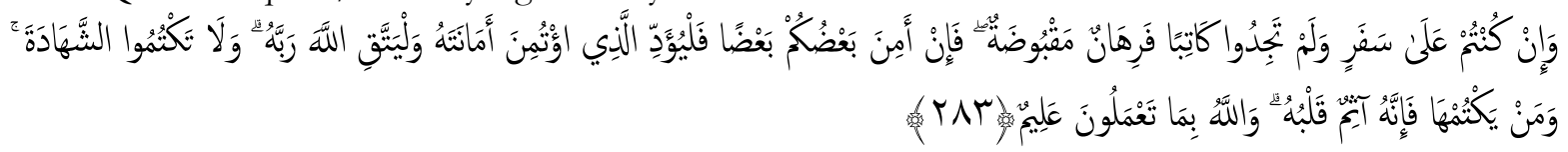

Terjemahannya :

"Iika kamu dalam perjalanan (dan bermu'amalah tidak secara tunai) sedang kamu tidak memperoleh seorang penulis, maka hendaklah ada barang tanggungan yang dipegang (oleh yang berpiutang). Akan tetapi jikea sebagian kamu mempercayai sebagian yang lain, maka hendaklah yang dipercayai itu menunaikan amanatnya (butangnya) dan hendaklah ia bertakwa kepada Allah Tuhannya; dan janganlah kamu (para saksi) menyembunyikan persaksian. Dan barangsiapa yang menyembunyikannya, maka sesunggubnya ia adalah orang yang berdosa hatinya; dan Allah Maha Mengetahui apa yang kamu kerjakan". ${ }^{19}$

Dalam islam kekayaan adalah amanah Allah yang tidak dapat dimiliki oleh siapapun secara mutlak, manusia diberi kebebasan bermuamalah selama bersama dengan ketentuan syariah dan manusia merupakan khalifah Allah, pemakmur dimuka bumi menjunjung tinggi keadilan, menolak setiap bentuk ribawi dan pemusatan sumber dana ekonomi

Bentuk kesejahteraan yang diberikan oleh koperasi pondok pesantren DDI Lilbanat berupa bidang produksi dan berupa jasa:

${ }^{18}$ Departemen Agama Republik Indonesia, Al-Qur'an Dan Terjemahan Babsa Indonesia (Bandung :Jumaanatul 'Alii-Art, 2004) h. 79.

${ }^{19}$ Departemen Agama Republik Indonesia, Al-Qur'an Dan Terjemahan Babsa Indonesia (Bandung :Jumaanatul 'Alii-Art, 2004) h. 49. 
a. Bidang produksi

Jenis usaha ini sangat potensial untuk dikembangkan, mengingat banyaknya harian santri, serta kebutuhan alat-alat tulis. Berdasarkan kegiatan usaha koperasi pondok pesantren (kopontren) DDI Lilbanat Parepare yang bergerak dalam berbagai usaha atau biasa dikenal dengan sebutan koperasi serba usaha, usaha koppontren DDI Lilbanat ini dapat menambah pemasukan kas koperasi, sehingga modal koperasi dapat bertambah. Usaha-usaha inilah yang membantu koperasi ini mendapatkan tambahan modal sehingga koperasi ini memiliki modal tambahan yang nantinya dapat berguna sehingga modal cadangan atau modal simpanan yang dapat digunakan atau untuk mengantisipasi apabila dalam kegiatan koperasi mengalami kekurangan.

\section{b. Bidang Jasa}

Sesuatu yang diharapkan dari koppontren DDI Lilbanat dalam meningkatkan kesejahteraan masyarakat di pondok pesantren DDI Lilbanat Parepare yaitu anggota guru dan santri pada khususnya dan masyarakat pada umumnya melalui kegiatan ekonomi pondok pesantren DDI Lilbanat parepare.

Dengan membeli perlengkapan sekolah di koperasi harganya relatif murah, sehingga banyak siswa yang lebih memilih membeli di koperasi sekolah dari pada membelinya di luar. Dengan memajukan koperasi sekolah, siswa akan terdidik menjadi generasi yang percaya bahwa koperasi merupakan saran untuk memenuhi kebutuhan ekonominya secara bersama-sama untuk mencapai kesejahteraan bersama. ${ }^{20}$

Dengan semakin banyaknya santri yang ada di pondok pesantren DDI Lilbanat dan juga semakin banyaknya kebutuhan mereka yang harus di penuhi, maka koperasi pondok pesantren DDI lilbanat tidak hanya bergerak di usaha sinpam pinjam saja melainkan sudah bergerak di bidang usaha toko dan usaha kantin pegawai. Pengembangan koperasi pondok pesantren DDI Lilbanat ini merupakan bagian dalam pertumbuhan ekonomi pondok pesantren DDI Lilbanat. Pengembangan usaha di bidang produksi ini bertujuan untuk mencukupi kebutuhan masyarakat di dalam pondok pesantren, sehingga mereka tidak merasa kesulitan dalam mencukupi kebutuhan sehari-harinya tanpa mereka keluar dari area pondok pesantren.

Koperasi pondok pesantren DDI Lilbanat dari tahun ke tahun berusaha melakukan perubahan secara perlahan-lahan dalam rangka memperbaiki perekonomian nasional yang bertujuan untuk mensejahterakan anggota pada khususnya, dan masyarakat pada umumnya. Semakin banyaknya santri di pondok pesantren DDI Lilbanat, maka kebutuhan mereka pun semakin beragam dan banyak. Dengan melihat kondisi tersebut, maka koperasi pondok pesantren DDI Lilbanat (koppontren) dari tahun ke tahun berusah untuk mengembangkan usahanya. Melalui kegiatan koperasi pondok pesantren DDI Lilbanat ini masyarakat di dalam pondok pesantren tidak merasa kesulitan dalam memenuhi kebutuhan sehari-harinya tanpa mereka keluar dari area pondok pesantren.

Dengan adanya koperasi sekolah, pihak sekolah termasuk siswa itu sendiri akan terbantu dalam memenuhi kebutuhan sarana dan prasarana sekolah seperti ATS (alat tulis sekolah). Koperasi sekolah merupakan wahana pembelajaran ekstrakurikuler yang kegiatannya terlepas dari kegiatan belajar, dan hanya merupakan kegiatan tambahan sekolah yang mempunyai ilmu dan manfaat yang sangat bagus. Bisa saja, para siswa yang telah lulus nanti dapat mendirikan koperasi.

Sebuah institusi yang kedudukannya berada di lingkungan pondok pesantren mempunyai nilai strategis dalam pengembangan kehidupan ekonomi di pondok pesantren pada posisi tertentu. Koppontren akan dapat menopang keberlangsungan aktifitas santri, ustadz dan kiyai di pesantren

${ }^{20}$ Kepustakaan Hadiyanto,Sistem Koperasi (Yogyakarta: BPFE Revisond Baswir, (2000). 
sedangkan sistem yang paling cocok untuk di terapkan pada koppontren mengenai perkoperasian di Indonesia. Kewenangan yang dimiliki oleh koperasi dapat berupa kegiatan penghimpunan dana melalui simpanan pokok, simpanan wajib dan simpanan manasuka, serta penyaluran dana kepada anggotanya.

Pengembangan koppontren Lilbanat mengalami kemajuan, hal ini dibuktikan dengan bertambahnya kegiatan usaha yang dikembangkan oleh koperasi pondok pesantren Lilbanat, misalnya saja usaha simpan pinjam, usaha kantin, usaha toko, usaha butik, usaha foto copy dan warnet. Bertambahnya usaha di koperasi pondok pesantren Lilbanat, anggota tidak mungkin dapat melaksanakan pengelolaan sendiri karena selain jumlah anggota yang terlalu banyak. Oleh karena itu, untuk dapat mengelola usaha koppontren Lilbanat secara efektif, anggota koppontren lilbanat memilih beberapa orang penguruskoperasi.

Menurut bapak syaiful Mahsan bahwa;

"Koperasi yang usahanya sudah besar, kegiatan usahanya dikelola oleh seorang pengelola yang membawahi banyak anggota untuk dapat menjalankan pekerjaanya dengan baik dan benar." 21

Salah satu konstribusi koppontren dalam meningkatkan kesejahteraan anggota di koperasi pondok pesantren Lilbanat yang bersifat material (ekonomi)

Menurut ibu Hj.Marhani Badaruddin

"Di antara semua bentuk upaya untuk meningkatkan kesejahteraan anggota yang manfaatnya dapat langsung dinikmati dan dapat dirasakan paling menonjol dalam memberikan kontribusinya bagi kesejahteraan anggota adalah dibidang simpan pinjam setiap anggota memerlukan dan mendadak dapat langsung pinjam ke koperasi."'22

Kesejahteraan yang diberikan koperasi pondok pesantren DDI Lilbanat sangat berarti dan bermanfaat untuk memenuhi kebutuhan fisik dan mental anggota beserta keluarganya maupun warga pondok pesantren DDI Lilbanat. Pemberian kesejahteraan akan menciptakan ketenangan, semangat kerja, dedikasi, disiplin, sikap loyal anggota terhadap koperasi. Kesejahteraan anggota adalah balas jasa pelengkap (material dan nonmaterial) yang diberikan berdasarkan kebijaksanaan. Tujuannya untuk mempertahankan dan memperbaiki kondisi fisik dan mental anggota agar produktivitas kerjanya meningkat.

Konstribusi dalam meningkatkan kesejahteraan guru dan santri atau masyarakat sekitar Pondok pesantren DDI Lilbanat. Di dalam kehidupan pondok pesantren, kebutuhan dapat bersifat individu maupun kolektif. Konsekuensinya, selalu ada upaya untuk memenuhi kebutuhan tersebut. Kebutuhan dapat dibedakan dalam berbagai kriteria, baik dilihat dari sifat, hierarki, maupun prioritasnya. Terpenuhinya kebutuhan pada prioritas pertama atau kebutuhan dasar akan mendorong usaha seseorang untuk memenuhi kebutuhan tidak pernah terhenti. Hal it disebabkan disamping karena adanya kebutuhan pada prioritas berikutnya yang menunggu untuk dipenuhi, juga karena kebutuhan itu berkembang dinamis sejalan dengan perkembangan pesantrennya. Suatu realitas kehidupan soasial yang menunjukkan semakin banyak kebutuhan terpenuhi dinamakan kondisi semakin sejahtera. Tidak mengherankan apabila dalam kehidupan pesantren selalu dijumpai proses atau usaha perubahan menuju kondisi yang semakin sejahtera tersebut. Salah satu usaha untuk menuju perubahan tersebut adalah dengan menggerakkan organisasi koperasi Pondok Pesantren DDI Lilbanat karena semakin

.21 Syaiful Mahsan, Ketua Koperasi Pondok Pesantren DDI Lilbanat Parepare, Wawancara, 25 Agustus 2017.

${ }^{22}$ Maharani Badaruddin, anggota Koperasi Pondok Pesanttren DDI Lilbanat Parepare, Wawancara, 14 Januari 2018. 
banyaknya santri yang belajar untuk mendalami agama Islam di Pondok Pesantren tersebut dan juga kebutuhan para santri yang semakin banyak. Adanya wadah koperasi ini, kerjasama, dan menambah keterampilan dalam berbagai hal serta memperluas pergaulan. Sehingga organisasi ini berdampak positif bagi anggotanya misalnya menambah pengetahuan dibidanh kewirausahaan yang dapat berguna dalam kehidupan sehari-hari.

Kesejahteraan yang diberikan koperasi pondok pesantren DDI Lilbanat ini sangat berarti dan bermanfaat untuk memenuhi kebutuhan fisik dan mental anggota beserta keluarganya untuk memenuhi kebutuhan fisik dan mental anggota beserta keluarganya maupun warga pondok pesantren DDI Lilbanat. Pemberian kesejahteraan akan menciftakan ketenangan, semangat kerja, didikasi, disiplin, sikap loyal anggota terhadap koperasi. Kesejahteraan anggota adalah balas jasa pelengkap (material dan nonmaterial) yang diberikan berdasarkan kebijaksanaan. Tujuannya untuk mempertahankan dan memperbaiki kondisi fisik dan mental anggota agar pruduktivitas kerjanya meningkat.

Dengan menambah usaha yang baru ini, koppontren bukan hanya menyediakan kebutuhan para anggota pondok pesantren DDI Lilbanat saja, melainkan juga dapat menyediakan kebutuhankebutuhan warga masyarakat sekitarnya. Kegiatan yang pernah dilaksanakan adalah koppontren pernah memberikan kesempatan kepada guru dan masyarakat sekitar pondok pesantren DDI Lilbanat untuk menjadi anggota koppontren dengan memberi izin berdagang atau memasok dagangan ke koppontren DDI Lilbanat dengan sistem bagi hasil. Dalam melaksanakan pogram kerja koperasi, koppontren DDI Lilbanat mencanangkan berbagai program sebagai pola kerja yang akan dijadikan acuan dalam rangka memenuhi standar keberhasilan program koperasi. Dalam mencanangkan program tersebut pengurus koperasi mengadakan musyawarah yang disebut koperasi (muskop) sebagai langkah awal dalam menentukan program mana saja yang dianggap efektif.

Koperasi pondok pesantren DDI Lilbanat Parepare dari tahun ke tahun berusaha melakukan perubahan secara perlahan-lahan dalam memperbaiki perekonomian nasional yang bertujuan untuk mensejahterakan anggota pada khususnya dan masyarakat pada umumnya. Semakin banyaknya santri di Pondok Pesantren DDI Lilbanat, maka kebutuhan mereka semakin beragam dan banyak. Dengan melihat kondisi tersebut, maka koperasi pondok pesantren DDI Lilbanat dari tahun ke tahun berusaha untuk mengembangkan usahanya. Selain itu koperasi Pondok Pesantren DDI Lilbanat sudah mempunyai kegiatan di usaha toko, usaha photocopy dan jasa simpan pinjam, Kegiatan-kegiatan tersebut ditujukan utuk mensejahterakan guru dan santri yang mengelola kegiatan-kegiatan kewirausahaan di koperasi Pondok Pesantren DDI Lilbanat.

Pengembangan usaha merupakan salah satu peningkatan kesejahteraan kepada guru dan santri dan masyarakat daerah Pondok pesantren dengan menambah kegiatan usaha di koperasi Pondok Pesantren DDI Lilbanat. Melalui kegiatan koperasi Pondok Pesantren DDI Lilbanat ini guru dan santri dan masyarakat di dalam Pondok Pesantren DDI Lilbanat tidak merasa kesulitan dalam memenuhi kebutuhan sehari-harinya tanpa mereka keluar dari area Pondok Pesantren.

Pengembangan usaha koperasi pondok pesantren DDI Lilbanat mengalami kemajuan, hal ini dibuktikan dengan bertambahnya kegiatan usaha yang dikembangkan oleh koperasi Pondok pesantren DDI Lilbanat, misalnya saja usaha simpan pinjam dan usaha toko. Bertambahnya usaha di koperasi pondok pesantren DDI Lilbanat, anggotanya tidak mungkin dapat melaksanakan pengelolaan sendiri karena selain jumlah anggota yang terlalu banyak juga karena tempat mereka yang terpencar-pencar.

Menurut Ibu ST. Awaliyah bahwa Upaya koperasi pondok pesantren dalam memenuhi kebutuhan guru dan santri bahwa;

"Pengurus koperasi melayani siswa-siswi yang kurang mampu dalam hal alat-alat tulis, buku, seragam dan lain-lain, dijual dengan harga yang sangat murah, dan dikoperasi juga melayani makan 
ringan, dan koperasi juga menyediakan simpan pinjam berupa uang bagi guru yang membutuhkan, disamping itu pengurus juga mengajari siswa siswi untuk bekoperasi atau bekerja sama dengan teman supaya nantinya setelah lulus siap pakai". ${ }^{23}$

Pelayanan yang diberikan oleh koperasi pondok pesantren DDI Lilbanat dalam pemenuhan kebutuhan. Dengan adanya pelayanan koperasi yang maksimal ini, maka akan memberikan konstribusi yang berarti, dalam menopang kebutuhan ekonomi anggotanya. Oleh karena itu koperasi pondok pesantren DDI Lilbanat dalam memberikan pelayanan yang baik kepada anggota di pondok pesantren.

Penuturan dari bapak Saiful Mahsan ketua koperasi pesantren tentang pelayanan koperasi pesantren kepada para konsumen;

"kami tetap berusaha memberikan pelayanan yang terbaik kepada konsumen meskipun terkadang masih ada konsumen yang merasa kecewa dengan pelayanan kami. Contoh pelayanan yang kami berikan misalnya kita langsung menyapa ketika ada konsumen y ang masuk ke koperasi dan selalu tersenyum jika berbicara dengan konsumen, menanyai pembeli jika si pembeli kebingungan mencari barang serta menunjukkan barang yang dicari oleh pembeli". ${ }^{24}$

Keramahan yang diberikan oleh anggota koperasi terhadap konsumen sangat berpengaruh bagi kemajuan koperasi pesantren karena dengan keramahan itu konsumen menjadi nyaman untuk selalu berbelanja kebutuhan sekolah. Koperasi sekolah melayani dan menyediakan barang-barang yang dibutuhkan semua warga sekolah dan warga sekitar lingkungan sekolah. Barang-barang yang disediakan di dalam koperasi sekolah tidak hanya barang atau peralatan sekolah saja melainkan juga menyediakan barang untuk kebutuhan sehari-hari, adapun barang-barang yang disediakan di koperasi sekolah Pondok pesantren DDI Lilbanat antara lain: Peralatan sekolah : buku tulis, buku gambar, pensil, bolpoint atau pena, tipex, penghapus, tempat pensil, papan kertas, pewarna (spidol), penggaris, stabilo, jangkar, gunting dan cutter, serta rautan dan kebutuhan lainnya : sabun, deterjen, gula pasir, teh, kopi, susu, roti, shampo, aneka minuman, makanan ringan, permen.

Koperasi pondok presantren DDI lilbanat ini merupakan wadah organisasi bagi santri yang dapat dijadikan sebagai tempat memberikan pelayanan kepada semua warga sekolah termasuk guru dan santri.

Program kerja yang di bentuk ketua koperasi dan pengurus dalam meningkatkan tanggung jawab karyawan dalam mengelola koperasi adalah dengan mempertimbangkan hal-hal apa saja yang dapat meningkatkan kualitas pelayanan yang diberikan kepada anggota koperasi dan pihak luar. Dalam meningkatkan kesejahteraan guru dan santri adalah menjadi program utama koperasi sekolah melalui pelayanan usaha. Jadi dengan utama pelayanan anggota (guru dan santri) merupakan prioritas utama dibandingkan dengan masyarakat umum. Manusia pada dasarnya adalah makhluk yang tidak pernah merasa puas, karena itu kesejahteraan akan terus dikejar tanpa batas. Keberhasilan koperasi dalam meningkatkan kesejahteraan sosial ekonomi anggotanya akan lebih mudah diukur, sehingga peningkatan kesejahteraan akan lebih mudah di ukur.

Tingkat kesejahteraan itu dapat ditandai dengan tinggi rendahnya pendapatan riil. Apabila pendapatan riil seseorang atau masyarakat meningkat, kesejahteraan ekonomi seseorang akan meningkat pula. Berkaitan dengan jalan pikiran tersebut, maka berarti pula tujuan koperasi ini di wujudkan dalam bentuk meningkatkan pendapatan riil pada anggotanya.

${ }^{23}$ HJ. ST. Awaliyah, Bendahara Koperasi Pondok Pesantren DDI Lilbanat Parepare, Wawancara, 25 Agustus 2017.

${ }^{24}$ Saiful Mahsan, Ketua Koperasi Pondok Pesantren DDI Lilbanat Parepare, Wawancara, 25 Agustus 2017. 
Untuk menunjang keberhasilan setiap kegiatan yang dibentuk oleh pondok pesantren DDI Lilbanat maupun kegiatan yang dibentuk oleh santri putra-putri, misalnya saja dalam rangka hari jadi pondok pesantren DDI Lilbanat, koperasi pondok pesantren DDI Lilbanat merupakan salah satu lembaga yang menjadi sponshorship dalam setiap kegiatan tersebut. Koppontren DDI Lilbanat selain ikut serta memeriahkan hari jadi pondok pesantren DDI Lilbanat, juga bertujuan untuk menjadi wadah untuk mempromosikan serat memperkenalkan produknya.

Sesuatu yang diharapkan dari koppontren DDI Lilbanat dalam meningkatkan kesejahteraan anggota di pondok pesantren DDI Lilbanat yaitu guru dan santri pada khususnya dan masyarakat pada umunya, melalui kegiatan ekonomi koperasi pondok pesantren. Peran koperasi dalam meningkatkan kesejahteraan anggota di pondok pesantren DDI Lilbanat yaitu menjalin kemitraan atau kerja sama. Koperasi pondok pesantren DDI Lilbanat ini telah menjalin kerjasama dengan berbagai kalangan baik instansi pemerintah maupun swasta untuk mewujudkan tujuan koperasi indonesia yaitu untuk meningkatkan kesejahteraan anggota. Kerja sama ini bertujuan untuk mengenalkan koppontren DDI Lilbanat dalam kalangan masyarakat agar mempermudah dalam pemasarannya, kerja sama ini juga diharapkan dapat memberikan modal agar koppontren bisa berkembang sehingga kesejahteraan anggota di pondok pesantren DDI Lilbanat khususnya guru dan santri dapat meningkat.

Salah satu konstribusi koperasi pondok pesantren DDI Lilbanat dalam meningkatkan kesejahteraan goru dan santri atau anggota di koperasi Pondok pesantren DDI lilbanat yang bersifat material (ekonomi). Membangun dan mengembangkan potensi serta kemampuan ekonomi anggota pada khususnya dan anggota pada umumnya untuk meningkatkan kesejahteraan ekonomi dan sosialnya. Berperan serta aktif dalam upaya mempertinggi kualitas kehidupan manusia dan masyarakat. Memperkokoh perekonomian anggota sebagai kekuatan dan ketahanan perekonomian dengan koperasi sebagai soko gurunya.

Menurut St.Aisyah bahwa;

"Koperasi pondok pesantren sudah meningkatkan kesejahteraan santri yang dulunya kebutuhan yang diinginkan tidak dapat terealisasi,sekarang sudah dapat terealisasi, sekarang sudah dapat terealisasikan dengan terpenuhinya semua kebutuhan yang diinginkan oleh santri dan bahkan dilayani dengan baik." 25

Peningkatan kesejahteraan tidak hanya dirasakan oleh anggota saja, tetapi juga dirasakan oleh para santri melalui kegiatan pengembangan kewirausahaan santri, misalnya saja latihan menjaga tokoh disaat istirahat. Pelatihan ini bertujuan untuk memberikan skill pada santri untuk melakukan usaha yang kongkrit dibidang kewirausahaan. Seperti yang dilakukan oleh salah satu santri yang bernama

Amila disaat mengisi waktu istirahatnya dengan menjaga kantin sekolah di pondok pesantren DDI Lilbanat.

"Ia kak mumpung lagi istirahat terus tidak ada terus tidak ada kerjaan jadinya saya bantuin jagain kantin, biar bisa tambah percaya diri ajah dan tidak malu lagi kak kalau besok jadi wirasawasta". ${ }^{26}$

Menurut ibu . ST. Awaliyah bahwa;

"Jadwal buka koperasi pesantren sehari-hari, untuk hari senin sampai hari kamis buka pukul 08.00 hingga pukul 15.00, dan untuk hari sabtu sampai minggu pukul 08.00 sampai pukul 13.00. pembagian jadwal piket sehari-hari rinciannya ada 4 anggota yang standby di koperasi pesantren,

${ }^{25}$ St.Aisyah, Santri Pondok Pesantren DDI Lilbanat Parepare, Wawancara, 14 Januari 2018

${ }^{26}$ Amila, Santri Pondok Pesantren DDI Lilbanat Ujung Lare Parepare, Wawancara,25Agustus2017. 
jadi setiap hari ada 4 kelas yang diambil satu anak untuk jaga koperasi pesantren, setiap anggota diwajibkan jaga di koperasi minimal dua dua kali dalam satu semester. Dikoperasi ini pembina, yang tersedia dikoperasi sekolah minimal Rp. 60.000"27

Dengan adanya program ini, siswa yang non pengurus juga akan mengetahui tentang perkoperasian dan pengelolaan barang di koperasi. Dalam upaya untuk menjadikan sebuah organisasi koperasi pondok pesantren yang terletak di dalam lembaga pendidikan pondok pesantren, peran dari pengurus koppontren selalu berupaya dengan terus berusaha semaksimal mungkin agar dapat mengoptimalkan keberadaan sebuah koppontren yang terletak ditengah-tengah kehidupan masyarakat pondok pesantren. Pelaksana harian bertugas mengelola usaha, administrasi dan keuangan. Pelaksanaan harian dapat diatur bergantian antar pengurus kopersi sekolah atau ditunjuk secara tetap atau bergantian antara siswa anggota koperasi yang tidak menduduki jabatan pengrus dan pengawas koperasi. Dalam, pelaksanaannya harus secara ketat ada pengawasan dari pihak guru atau pegawai sekolah misalnya tata usaha, karena tanpa pengawasan dari pihak sekolah, koperasi sekolah kesulitan karena siswa yang diberi tanggung jawab masih memerlukan petunjuk dan bimbingan.

Suatu organisasi memerlukan suatu pengelolaan agar kegiatan organisasi dapat berjalan dengan lancar, efektif dan efisien. Selain itu dengan adanya pengelolaan maka proses pencapaian tujuan organisasi dapat berjalan secara terstruktur sesuai dengan rencana yang di tetapkan. Pengelolaan adalah serangkaian kegiatan yang merencanakan, mengorganisasikan, menggerakkan dan mengembangkan terhadap segala upaya dalam mengatur dan mendayagunakan sumber daya manusia.

\section{Kesimpulan}

Berdasarkan dari hasil penelitian dan pembahasan yang telah dijelaskan, maka kesimpulan yang dapat ditarik adalah sebagai berikut;

1. Upaya koperasi Pondok Pesantren DDI Lilbanat dalam memenuhi kebutuhan dan meningkatkan kesejahteraan guru dan santri, yaitu dengan memperbaiki baik itu kegiatan-kegiatan koperasi, pengelolaan unit-unit usahanya maupun manajemen koperasinya agar kebutuhan anggota (guru dan santri) terpenuhi dan kesejahteraan anggota pun dapat meningkat.

2. Fungsi koperasi pondok pesantren DDI Lilbanat dalam rangka meningkatkan kesejahteraan guru dan santri, yaitu membangun dan mengembangkan potensi dan kemampuan ekonomi anggota (guru dan santri), membantu kebutuhan anggota, menumbuhkan kesadaran berkoperasi dan membina rasa tanggung jawab, disiplin serta berjiwa koperasi.

${ }^{27}$ HJ. ST. Awaliyah, Bendahara Koperasi Pondok Pesantren DDI Lilbanat Parepare, Wawancara, 25 Agustus 2017. 


\section{Daftar Pustaka}

Azwar, Saifuddin.2000. Metode Penelitian. Cet. II. Yogyakarta: Pustaka Pelajar.

Azyumardi, Azra. 1997. Pesantren, Kontinuitas dan Perubahan, dalam bilik-bilik Pesantren. Jakarta : paramadina.

Departemen Agama RI. 1971. Al-Quran dan Terjemahan. Jakarta: Yayasan Peyelenggara Penerjemahan/penafsiran al-quran.

Hadiyanto. 2000. Sistem Koperasi. Yogyakarta: BPFE Revisond Baswir.

Hendar. 1999. Ekonomi Koperasi. Jakarta : FE-UI.

Justama. 2015. Skripsi. Peran PNPM Terbadap Peningkatan Kesejabteraa Masyarakat Miskin di Keluraban Bittoeng Kecamatan Duampanua Kabupaten Pinrang.

Kartasapoetra, G. 2005. Praktek. Pengelolaan Koperasi. Jakarta: PT. Rineka Cipta.

Ningsi, Irian Murni. 1992. Koperasi Indonesia. Bandung: Pringgandani.

Pusat Bahasa. 2008. Kamus Besar Bahasa Indonesia. Edisi keempat. Gramedia Pustaka Utama.

Riyanto, Eko Trisno. 2011/2012. Skripsi. Peran Koperasi dalam Mengatur Cash Flow Para Santri, Studi Kasus di Koperasi At-Taslim Desa Bintaro kecamatan Demak Kabupaten Demak.

Robiasih, Hartaty. Peran Aktif Anggota Dalam Mensejabterakan Koperasi.htm

Rudianto. Akuntansi Koperasi. PT Gelora Aksara Pratama.

Sitio, Arifin. Halomoan Tamba. 2001. Koperasi: Teori dan Praktek. Jakarta: Erlangga.

Subagyo, Joko. 2006. Metode Penelitian: Dalam teori praktek. Jakarta: Rineka Cipta.

Sugiyono. 2002. Statistik Untuk Penelitian. Bandung: CV. Alfabet.

Sunundia. Ninik Widiyanti. Koperasi dan Perekonomian Indonesia. Jakarta: PT Rineka Cipta dan PT Bina Adiaksara.

Supardan, Dadang. 2008. Pengantar Ilmu Sosial. Jakarta: Bumi Aksara.

Tamban, Holomoan. Arifin Sitio. Koperasi : Teori Dan Praktek. Jakarta : PT. Gelora Aksara Pratam.

Tim Penyusun Pedoman Penulisan Karya Ilmiah. 2013. Makalah dan Skripsi. Edisi Revisi. Parepare: Stain Parepare.

Tujuan, Fungsi dan Peran Koperasi Indonesia _ Pengertian Pakar.htm.

Widiyanti, Ninik. 1989. Koperasi dan Perekonomian Indonesia. Jakarta : Bina Adiaksara.

Widiyanti, Ninik. Manajemen Koperasi. Jakarta: PT Rineka Cipta.

Widiyanti, Ninik. Koperasi perekonomian Indonesia. Jakarta: PT Rineka dan PT Bina Adiaksara. 
Hikmawati, Syahriyah Semaun, Damira

\section{Referensi dari Internet}

Zainuddin. Masyhuri. Metode Penelitian (Pendekatan Praktis dan Apikatif).

http://www.asian-spirit. Blogspot.com/2009/12/ pengenalan koperasi sekolah di akses 9 november 2012. https://id.m.wikipedia.org/wiki/kesejahteraan 23 februari 2016.

http://www.materibelajar.id/2016/01/defenisi-peran-dan-pengelompokan-peran.

http://www.artikelsiana.com/2014/10/pengertian-defenisi-fungsi-peran. 